\title{
Efektivitas Penggunaan Kertas Origami Materi Keliling dan Luas Bangun Datar Kelas IV SD
}

\author{
I'in Dwi Astuti \\ Universitas Tanjungpura Pontianak \\ iindwiastuti0303@student.untan.ac.id
}

Hamdani

Universitas Tanjungpura Pontianak

hamdani.mikraj@fkip.untan.ac.id

\section{Rio Pranata}

Universitas Tanjungpura Pontianak

riopranata@fkip.untan.ac.id

\begin{abstract}
This study aims to determine the effectiveness of using origami paper in learning the circumference and area of a flat shape in class IV SDN 05 East Pontianak. The methode of research used in this research is experiment. The form of research is One-Shot Case Study. The data source of this research is SDN 05 East Pontianak. The subjects in the study were 26 students. The data in this study are the results of observations of the teacher's ability to carry out learning starting from pre-activities, learning activities and closing activities. Student activities in terms of mental activities, listening, visual, writing and oral activities. Learning outcomes (post-test) in the form of short essay. The results showed that the teacher's ability to carry out the learning obtained $R K G_{\text {total }}=2.74$ in the "good" category. The average activity of students obtained a total percentage of $62 \%$ with the category "quite active". Student learning outcomes in this study obtained $76.92 \%$ completeness with the "good" category. Based on the results of the study, it shows that the use of origami paper in mathematics learning about the circumference and area of a flat shape for class IV SDN 05 East Pontianak is ineffective.
\end{abstract}

Keywords : Effectiveness, Origami Paper, Circumference and Area of a Flat Shape

\section{Pendahuluan}

Pendidikan merupakan suatu proses untuk mengarahkan peserta didik agar mampu mengembangkan potensi-potensi peserta didik mencapai tujuan pendidikan nasional (Undang-Undang No.20 tahun 2003 pasal 3). Untuk mencapai tujuan tersebut, pendidikan nasional diperlukan kualifikasi, kompetensi dan jenjang pendidikan yang menunjang peserta didik. Hal tersebut juga diperkuat dalam Undang-undang Nomor 20 tahun 2016 bahwa "standar kompetensi lulusan terdiri atas kriteria kualifikasi yang diharapkan dapat mencapai kemampuan-kemampuan tertentu setelah menyelesaikan masa belajarnya di satuan pendidikan pada jenjang pendidikan dasar".

Pada jenjang pendidikan dasar khususnya sekolah dasar memiliki 8 mata pelajaran salah satunya matematika. Pembelajaran matematika memiliki bekal bagi peserta didik untuk berfikir logis, analitis, sistematis, kritis dan kreatif (Sundayana, 2014: 2). Apabila peserta didik memiliki bekal tersebut maka akan meningkatkan mutu 
pembelajaran. Meningkatnya mutu pembelajaran juga akan meningkatkan sumber daya manusia yang berkualitas dan mampu bersaing dengan negara lainnya.

Namun pada kenyataannya, Programme for Internasional Student Assessment (PISA) mencatat kemampuan matematika siswa Indonesia mendapatkan skor 379 di tahun 2018 dengan peringkat kelima dari bawah yang diikuti 80 negara, sebelumnya Indonesia memiliki skor matematika 386 di tahun 2015. Dari hasil tersebut menunjukkan bahwa tingkat kemampuan peserta didik Indonesia tergolong rendah dibidang matematika (Dewabrata, 2019).

Hal ini juga diperkuat dengan pra-riset kepada 3 peserta didik kelas V B yang sudah mempelajari materi keliling dan luas persegi panjang, persegi dan segitiga. Hal tersebut terlihat bahwa kesalahan pengerjaan soal karena peserta didik salah dalam menggunakan rumus dan rumus yang digunakan pun tertukar. Pada hasil tersebut juga menunjukkan nilai rata-rata 41,02. Dengan hasil 2 orang mendapatkan nilai 38,46 dan satu orang mendapatkan nilai 46,15. Hasil ini menunjukkan bahwa tiga peserta didik tidak mencapai nilai KKM.

Berdasarkan informasi bahwa peserta didik tidak mampu memahami konsep, rumus sering tertukar dan peserta didik mudah lupa dengan rumus. Pada proses pembelajaran guru tidak menggunakan media pembelajaran saat proses pembelajaran, sehingga mengakibatkan peserta didik cenderung mudah lupa.

Peserta didik harus diberikan stimulus visual dan verbal agar tidak mudah lupa dan dapat memahami konsep pada pembelajaran. Menurut Levie \& Levie (dalam Arsyad, 2014: 2) "stimulus visual mendapatkan hasil belajar yang lebih baik daripada mengingat, mengenali, mengingat kembali dan menghubung-hubungkan fakta serta konsep sedangkan stimulus verbal memberikan hasil belajar yang besar apabila pembelajaran itu melibatkan ingatan berurut-urut". Proses pembelajaran juga memerlukan alat bantu untuk menyampaikan materi pembelajaran. Sejalan dengan itu Sadiman, et., al. (2014: 7) ) mengatakan bahwa "media sebagai alat bantu mengajar guru, alat bantu yang dipakai adalah visual misalnya gambar, model, objek dan alat-alat lain yang dapat memberikan pengalaman konkret, motivasi serta meninggikan daya serap dan retensi belajar siswa".

Penggunaan media pembelajaran akan memudahkan peserta didik untuk mendapatkan pesan dari materi, pembelajaran pun akan lebih menarik. Menurut Arsyad (2014: 15) "penggunaan media pembelajaran pada tahap orientasi pembelajaran akan membantu keefektifan dalam proses pembelajaran dan menyampaikan pesan serta isi pelajaran pada saat itu". Pembelajaran matematika akan juga lebih efektif jika dilakukan dengan menggunakan media pembelajaran. Pendapat ini sejalan dengan pendapat Hamalik (dalam Arsyad, 2014: 1) "penggunaan media pembelajaran dalam proses mengajar dapat membangkitkan keinginan dan minat yang baru, membangkitkan motivasi dan merangsang kegiatan belajar dan bahkan membantu pengaruh-pengaruh psikologi terhadap siswa".

Salah satu media belajar matematika yang tepat untuk memahami materi keliling dan luas bangun datar adalah dengan menggunakan media manipulatif. Menurut Muhsetyo (2011: 2.1) "media manipulatif adalah alat bantu yang digunakan terutama untuk menjelaskan konsep dan prosedur matematika". Alat ini bagian langsung dari mata pelajaran matematika serta dapat dimanipulasikan misalnya dibalik, dipotong, digeser, dipindah, digambar, ditambah,dipilih, dikelompokkan atau diklasifikasikan.

Menurut Muhsetyo (2011: 52) "media manipulatif memiliki macam-macam dalam pembelajaran matematika yaitu: (1) bahan manipulatif dari kertas, (2) model stik, (3) model persegi dari kayu/triplek, (4) model kertas bertitik/berpetak. Penelitian ini 
menggunakan bahan manipulatif dari kertas". Bahan kertas yang digunakan merupakan kertas origami yang telah dipotong menjadi bentuk persegi berukuran 1 $\mathrm{cm}$ pada masing-masing sisinya. Dengan menggunakan kertas origami dalam pembelajaran matematika diharapkan peserta didik dapat termotivasi untuk mempelajari matematika sehingga tercipta proses pembelajaran menyenangkan dan memudahkan peserta didik memahami materi keliling dan luas bangun datar.

Wabah corona virus disease (COVID-19) sedang melanda 215 negara di dunia termasuk Indonesia. COVID-19 menimbulkan dampak yang sangat besar diberbagai sektor termasuk pendidikan. Hal ini juga menyebabkan pembelajaran yang biasa dilakukan secara luring harus dilakukan secara daring. Salah satu seklah yang melaksanakan pembelajaran secara daring adalah di sekolah SDN 05. SDN 05 Pontianak Timur melakukan pembelajaran daring dengan 2 teknis yaitu dengan berkomunikasi lewat aplikasi whatsapp dan menggunakan aplikasi zoom atau meet. Melihat kondisi tersebut penelitan ini menggunakan aplikasi whatsapp dan aplikasi meet dalam menyampaikan pembelajaran.

Karena penelitian daring baru pertama kali dilakukan maka peneliti tertarik untuk mengkaji Efektivitas Penggunaan Kertas Origami pada Materi Keliling dan Luas Bangun Datar khususnya pada peserta didik kelas IV SDN 05 Pontianak Timur.

\section{Metode}

Menurut Syaodih (2016: 52) bahwa "metode penelitian merupakan kegiatan pelaksanaan penelitian yang didasari oleh asumsi-asumsi, pandangan filosofis dan ideologis tentang pertanyaan dan isu-isu yang sedang dihadapi”. Menurut Sugiyono (2019: 2) bahwa "metode penelitian adalah cara ilmiah untuk mendapatkan data dengan tujuan dan kegunaan tertentu".

Metode yang digunakan adalah metode eksperimen dalam bentuk kuantitatif deskriptif. Metode eksperimen dalam penelitian ini berguna untuk mencari pengaruh suatu perlakuan tertentu terhadap sesuatu yang lainnya. Pemilihan metode eksperimen dalam penelitian ini adalah melihat keefektivitas pembelajaran kertas origami pada pembelajaran matematika materi keliling dan luas bangun datar di kelas IV Sekolah Dasar Negeri 05 Pontianak Timur.

Menurut Sugiyono (2019: 11), bentuk desain ekperimen yang dapat digunakan adalah : "Pre-Eksperimental Design, True Eksperimen Desain, Factorial Design dan Quasi Eksperimental Design. Bentuk dalam penelitian ini adalah Pre-Eksperimen Design. Bentuk Pre-Eksperimental Disigns memiliki beberapa macam yaitu One Shot Case Study, One Grop Pretest-Posttest Design, Intact Group Comparison” (h.112). Karena dalam penelitian menggunakan perlakuan kertas origami maka penelitian ini menggunakan One-Shot Case Study. Pandangan penelitian ini sebagai berikut :

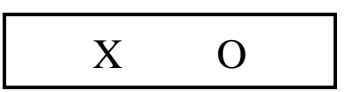

(Sugiyono, 2019: 113).

Keterangan :

X $\quad$ : Kertas Origami (Variabel Independen).

O : Observasi (Variabel Dependen).

Paradigma itu dapat dibaca terdapat peserta didik diberi treatment/perlakuan dan selanjutnya diobservasi hasilnya. Menurut Sugiyono (2019: 113) bahwa "treatment adalah sebagai variabel independen dan hasil adalah sebagai variabel dependen". Dari paradigma di atas dapat digambarkan bahwa variabel independen penelitian ini 
adalah penerapan kertas origami pada proses pembelajaran. Sedangkan variabel dependen merupakan hasil dari penerapan kertas origami. Subjek penelian ini berjumlah 26 peserta didik Sekolah Dasar Negeri 05 Pontianak Timur. Data yang dikumpulkan berupa lembar observasi kemampuan guru, aktivitas peserta didik, dan hasil belajar (post-test).

\section{Hasil}

Penelitian ini dilakukan untuk menganalisis dan mengetahui efektivitas pembelajaran kertas origami pada pembelajaran matematika materi keliling dan luas bangun datar kelas IV Sekolah Dasar 05 Pontianak Timur. Hasil dan pembahasan penelitian ini berdasarkan manfaat penelitian diatas yang sebagaimana telah dituliskan pada bab sebelumnya.

Penelitian ini dilaksanakan dengan cara daring (Online), karena dimasa pandemi tidak dapat melaksanakan pembelajaran secara tatap muka. Penelitian dilaksanakan pada tanggal 12 November 2020 sampai 17 November 2020 sebanyak tiga kali pertemuan di Sekolah Dasar Negeri 05 Pontianak Timur. Jumlah subjek terdiri dari 12 laki-laki dan 14 perempuan. Data yang diperoleh berupa hasil observasi kemampuan guru melaksanakan pembelajaran, observasi aktivitas peserta didik dan hasil belajar (Post-Test). Penelitian ini di observasi oleh ibu Melvika Fitriani, S.Pd sebagai guru kelas IV A Sekolah Dasar Negeri 05 Pontianak Timur.

\section{Hasil Observasi Kemampuan Guru}

Observasi kemampuan guru ini dilakukan sebanyak tiga kali pertemuan. Hasil dari pengamatan tersebut dianalisis dan diolah sehingga diperoleh hasil sebagai berikut:

Tabel 1.Hasil Observasi Kemampuan Guru Melakasanakan Pembelajaran dengan Menerapkan Media Kertas Origami pada Pembelajaran Matematika

\begin{tabular}{|c|c|c|c|c|c|}
\hline \multirow{2}{*}{ No } & \multirow{2}{*}{ Kegiatan } & \multirow{2}{*}{ Pelaksanaan Pembelajaran } & \multicolumn{3}{|c|}{ Jumlah Skor } \\
\hline & & & 1 & 2 & 3 \\
\hline 1 & Pendahuluan & $\begin{array}{l}\text { Guru memberikan salam dan menyapa } \\
\text { peserta didik }\end{array}$ & 4 & 3 & 4 \\
\hline 2 & & Guru mengajak peserta didik berdoa & 3 & 3 & 3 \\
\hline 3 & & Guru memeriksan kehadiran peserta didik & 4 & 3 & 4 \\
\hline 4 & & Guru memberikan apersepsi & 3 & 3 & 2 \\
\hline 5 & & Guru memberikan informasi & 4 & 2 & 3 \\
\hline 6 & & Guru menyampaikan tujuan pembelajaran & 3 & 2 & 3 \\
\hline 7 & Inti & Mendemonstrasikan media kertas origami & 2 & 2 & 3 \\
\hline 8 & & Memberikan kesempatan bertanya & 3 & 2 & 3 \\
\hline 9 & & $\begin{array}{l}\text { Membimbing peserta didik saat melakukan } \\
\text { LKPD }\end{array}$ & 2 & 2 & 3 \\
\hline 10 & & Guru berkomunikasi dengan baik & 2 & 2 & 2 \\
\hline 11 & Penutup & Menyimpulkan pelajaran & 2 & 2 & 2 \\
\hline 12 & & Tindak lanjut & 2 & 3 & 3 \\
\hline 13 & & Berdoa'a dan Mengucapkan salam & 3 & 3 & 3 \\
\hline \multicolumn{2}{|c|}{ Jumlah } & & 37 & 32 & 38 \\
\hline \multicolumn{2}{|c|}{$R G K_{i}$} & & 2,85 & 2,46 & 2,92 \\
\hline \multicolumn{2}{|c|}{$R K G_{\text {total }}$} & & & & 2,74 \\
\hline
\end{tabular}


Keterangan

Baik

Dari tabel 1 skor kemampuan guru dalam melaksanakan pembelajaran pertemuan pertama adalah 2,85 dengan kategori baik, skor kemampuan guru dalam melaksanakan pembelajaran pertemuan kedua adalah 2,46 dengan kategori baik, dan skor kemampuan guru dalam melaksanakan pembelajaran pertemuan ketiga adalah 2,93 dengan kategori baik. Skor rata-rata kemampuan guru dalam melaksanakan pembelajaran adalah 2,74 dengan katagori "baik".

\section{Hasil Observasi Aktivitas Peserta Didik}

Observasi aktivitas peserta didik dilakukan sebanyak tiga kali pertemuan. Lembar observasi aktivitas peserta didik ini diamati oleh ibu Melvika Fitriani, S.Pd. Hasil pengamatan aktivitas peserta didik diperoleh sebagai berikut.

Tabel 2. Hasil Observasi Aktivitas Peserta Didik Pertemuan 1

\begin{tabular}{|c|c|c|c|c|c|}
\hline No & Kegiatan & $\begin{array}{c}\text { Aktivitas Belajar Peserta } \\
\text { Didik }\end{array}$ & $\mathbf{f}$ & Persentase & $\begin{array}{l}\text { Persentase } \\
\text { Setiap } \\
\text { Kegitan }\end{array}$ \\
\hline 1 & \multirow{7}{*}{ Mental } & $\begin{array}{l}\text { Memberikan pendapat/ } \\
\text { jawaban secara } \\
\text { lisan/menanggapi pertanyaan } \\
\text { dari guru }\end{array}$ & 12 & $46 \%$ & \multirow{7}{*}{$57 \%$} \\
\hline 2 & & $\begin{array}{l}\text { Melaksanakan kegiatan LKPD } \\
\text { sampai batas waktu yang di } \\
\text { tentukan. }\end{array}$ & 22 & $85 \%$ & \\
\hline 3 & & $\begin{array}{l}\text { Memberikan tanggapan ketika } \\
\text { teman yang lain presentasi }\end{array}$ & 6 & $23 \%$ & \\
\hline 4 & & $\begin{array}{l}\text { Menanyakan hal-hal yang } \\
\text { belum dipahami pada masalah } \\
\text { di LKPD }\end{array}$ & 24 & $92 \%$ & \\
\hline 5 & & $\begin{array}{l}\text { Membuat kesimpulan materi } \\
\text { yang diberikan }\end{array}$ & 18 & $69 \%$ & \\
\hline 6 & & $\begin{array}{l}\text { Mengajukan pertanyaan pada } \\
\text { saat proses pembelajaran }\end{array}$ & 20 & $77 \%$ & \\
\hline 7 & & $\begin{array}{l}\text { Memperbaiki atau } \\
\text { menambahkan kesimpulan } \\
\text { temannya jika kesimpulan } \\
\text { temannya belum lengkap }\end{array}$ & 2 & $8 \%$ & \\
\hline 8 & \multirow{4}{*}{ Menyimak } & $\begin{array}{l}\text { Mendengar informasi yang } \\
\text { disampaikan oleh guru }\end{array}$ & 20 & $77 \%$ & \multirow{4}{*}{$78 \%$} \\
\hline 9 & & $\begin{array}{l}\text { Mendengar penjelasan dari } \\
\text { guru/ presentasi teman }\end{array}$ & 24 & $92 \%$ & \\
\hline 10 & & $\begin{array}{l}\text { Memperhatikan teman yang } \\
\text { menyampaikan pendapat }\end{array}$ & 17 & $65 \%$ & \\
\hline 11 & & $\begin{array}{l}\text { Mendengarkan kesimpulan dari } \\
\text { teman. }\end{array}$ & 20 & $77 \%$ & \\
\hline 12 & Visual & $\begin{array}{l}\text { Memperhatikan guru saat } \\
\text { menyampaikan apersepsi }\end{array}$ & 22 & $85 \%$ & $85 \%$ \\
\hline 13 & Menulis & $\begin{array}{l}\text { Mencatat kesimpulan atau } \\
\text { rangkuman materi yang } \\
\text { diberikan }\end{array}$ & 14 & $54 \%$ & $54 \%$ \\
\hline 14 & \multirow{2}{*}{ Lisan } & Menjawab salam guru & 23 & $88 \%$ & \multirow{2}{*}{$88 \%$} \\
\hline 15 & & Menjawab salam penutup guru & 23 & $88 \%$ & \\
\hline \multicolumn{3}{|c|}{ Rata-Rata } & & & $72 \%$ \\
\hline \multicolumn{2}{|c|}{ Keterangan } & & & & $\begin{array}{c}\text { Cukup } \\
\text { aktif }\end{array}$ \\
\hline
\end{tabular}


Berdasarkan hasil tabel 2 aktivitas peserta didik memiliki 5 indikator kegiatan. Indikator kegiatan mental dengan tujuh aktivitas belajar peserta didik mendapatkan $57 \%$. Indikator menyimak dengan empat aktivitas belajar peserta didik mendapatkan $78 \%$. Indikator visual dengan satu aktivitas mendapatkan $85 \%$. Indikator menulis dengan satu aktivitas belajar peserta didik mendapatkan 54\%. Indikator kegiatan lisan dengan dua aktivitas belajar peserta didik mendapatkan 88\%. Rata-rata 5 indikator kegiatan mendapatkan $72 \%$ dengan kategori "cukup aktif".

Tabel 3. Hasil Observasi Aktivitas Peserta Didik Pertemuan 2

\begin{tabular}{|c|c|c|c|c|c|}
\hline No & Kegiatan & $\begin{array}{l}\text { Aktivitas Belajar } \\
\text { Peserta Didik }\end{array}$ & f & Persentase & $\begin{array}{c}\text { Persentase } \\
\text { Setiap } \\
\text { Kegitan }\end{array}$ \\
\hline 1 & \multirow{7}{*}{ Mental } & $\begin{array}{l}\text { Memberikan pendapat/ } \\
\text { jawaban secara } \\
\text { lisan/menanggapi } \\
\text { pertanyaan dari guru }\end{array}$ & 11 & $42 \%$ & \multirow{7}{*}{$39 \%$} \\
\hline 2 & & $\begin{array}{l}\text { Melaksanakan kegiatan } \\
\text { LKPD sampai batas waktu } \\
\text { yang di tentukan. }\end{array}$ & 15 & $58 \%$ & \\
\hline 3 & & $\begin{array}{l}\text { Memberikan tanggapan } \\
\text { ketika teman yang lain } \\
\text { presentasi }\end{array}$ & 3 & $12 \%$ & \\
\hline 4 & & $\begin{array}{l}\text { Menanyakan hal-hal yang } \\
\text { belum dipahami pada } \\
\text { masalah di LKPD }\end{array}$ & 20 & $77 \%$ & \\
\hline 5 & & $\begin{array}{l}\text { Membuat kesimpulan } \\
\text { materi yang diberikan }\end{array}$ & 3 & $12 \%$ & \\
\hline 6 & & $\begin{array}{l}\text { Mengajukan pertanyaan } \\
\text { pada saat proses } \\
\text { pembelajaran }\end{array}$ & 16 & $62 \%$ & \\
\hline 7 & & $\begin{array}{l}\text { Memperbaiki atau } \\
\text { menambahkan kesimpulan } \\
\text { temannya jika kesimpulan } \\
\text { temannya belum lengkap }\end{array}$ & 3 & $12 \%$ & \\
\hline 8 & \multirow{4}{*}{ Menyimak } & $\begin{array}{l}\text { Mendengar informasi yang } \\
\text { disampaikan oleh guru }\end{array}$ & 19 & $73 \%$ & \multirow{4}{*}{$68 \%$} \\
\hline 9 & & $\begin{array}{l}\text { Mendengar penjelasan dari } \\
\text { guru/ presentasi teman }\end{array}$ & 23 & $88 \%$ & \\
\hline 10 & & $\begin{array}{l}\text { Memperhatikan teman } \\
\text { yang menyampaikan } \\
\text { pendapat }\end{array}$ & 15 & $58 \%$ & \\
\hline 11 & & $\begin{array}{l}\text { Mendengarkan kesimpulan } \\
\text { dari teman. }\end{array}$ & 14 & $54 \%$ & \\
\hline 12 & Visual & $\begin{array}{l}\text { Memperhatikan guru saat } \\
\text { menyampaikan apersepsi }\end{array}$ & 18 & $69 \%$ & $69 \%$ \\
\hline 13 & Menulis & $\begin{array}{l}\text { Mencatat kesimpulan atau } \\
\text { rangkuman materi yang } \\
\text { diberikan }\end{array}$ & 13 & $50 \%$ & $50 \%$ \\
\hline 14 & \multirow[b]{2}{*}{ Lisan } & Menjawab salam guru & 22 & $85 \%$ & \multirow{2}{*}{$81 \%$} \\
\hline 15 & & $\begin{array}{l}\text { Menjawab salam penutup } \\
\text { guru }\end{array}$ & 20 & $77 \%$ & \\
\hline \multicolumn{3}{|c|}{ Rata-Rata } & & & $61 \%$ \\
\hline Kete & ngan & & & & Pasif \\
\hline
\end{tabular}

Berdasarkan hasil tabel 3 aktivitas peserta didik memiliki 5 indikator kegiatan. Indikator kegiatan mental dengan tujuh aktivitas belajar peserta didik mendapatkan $39 \%$. Indikator menyimak dengan empat aktivitas belajar peserta didik mendapatkan $68 \%$. Indikator visual dengan satu aktivitas mendapatkan $69 \%$. Indikator menulis 
dengan satu aktivitas belajar peserta didik mendapatkan 50\%. Indikator kegiatan lisan dengan dua aktivitas belajar peserta didik mendapatkan 81\%. Rata-rata 5 indikator kegiatan mendapatkan 61\% dengan kategori "pasif".

Tabel 4. Hasil Observasi Aktivitas Peserta Didik Pertemuan 3

\begin{tabular}{|c|c|c|c|c|c|}
\hline No & Kegiatan & $\begin{array}{c}\text { Aktivitas Belajar Peserta } \\
\text { Didik }\end{array}$ & $\mathbf{F}$ & Persentase & $\begin{array}{c}\text { Persentase } \\
\text { Setiap } \\
\text { Kegiatan } \\
\end{array}$ \\
\hline 1 & \multirow{7}{*}{ Mental } & $\begin{array}{l}\text { Memberikan pendapat/ jawaban } \\
\text { secara lisan/menanggapi } \\
\text { pertanyaan dari guru }\end{array}$ & 15 & $58 \%$ & \multirow{7}{*}{$49 \%$} \\
\hline 2 & & $\begin{array}{l}\text { Melaksanakan kegiatan LKPD } \\
\text { sampai batas waktu yang di } \\
\text { tentukan. }\end{array}$ & 23 & $88 \%$ & \\
\hline 3 & & $\begin{array}{l}\text { Memberikan tanggapan ketika } \\
\text { teman yang lain presentasi }\end{array}$ & 5 & $19 \%$ & \\
\hline 4 & & $\begin{array}{l}\text { Menanyakan hal-hal yang belum } \\
\text { dipahami pada masalah di LKPD }\end{array}$ & 23 & $88 \%$ & \\
\hline 5 & & $\begin{array}{l}\text { Membuat kesimpulan materi yang } \\
\text { diberikan }\end{array}$ & 2 & $8 \%$ & \\
\hline 6 & & $\begin{array}{l}\text { Mengajukan pertanyaan pada } \\
\text { saat proses pembelajaran }\end{array}$ & 19 & $73 \%$ & \\
\hline 7 & & $\begin{array}{l}\text { Memperbaiki atau menambahkan } \\
\text { kesimpulan temannya jika } \\
\text { kesimpulan temannya belum } \\
\text { lengkap }\end{array}$ & 2 & $8 \%$ & \\
\hline 8 & \multirow{4}{*}{ Menyimak } & $\begin{array}{l}\text { Mendengar informasi yang } \\
\text { disampaikan oleh guru }\end{array}$ & 19 & $73 \%$ & \multirow{4}{*}{$63 \%$} \\
\hline 9 & & $\begin{array}{l}\text { Mendengar penjelasan dari guru/ } \\
\text { presentasi teman }\end{array}$ & 20 & $77 \%$ & \\
\hline 10 & & $\begin{array}{l}\text { Memperhatikan teman yang } \\
\text { menyampaikan pendapat }\end{array}$ & 16 & $62 \%$ & \\
\hline 11 & & $\begin{array}{l}\text { Mendengarkan kesimpulan dari } \\
\text { teman. }\end{array}$ & 10 & $38 \%$ & \\
\hline 12 & Visual & $\begin{array}{l}\text { Memperhatikan guru saat } \\
\text { menyampaikan apersepsi }\end{array}$ & 19 & $73 \%$ & $73 \%$ \\
\hline 13 & Menulis & $\begin{array}{l}\text { Mencatat kesimpulan atau } \\
\text { rangkuman materi yang diberikan }\end{array}$ & 10 & $38 \%$ & $38 \%$ \\
\hline 14 & \multirow{2}{*}{ Lisan } & Menjawab salam guru & 25 & $96 \%$ & \multirow{2}{*}{$94 \%$} \\
\hline 15 & & Menjawab salam penutup guru & 24 & $92 \%$ & \\
\hline \multicolumn{3}{|c|}{ Rata-Rata } & & & $63 \%$ \\
\hline \multicolumn{3}{|c|}{ Keterangan } & & & Pasif \\
\hline
\end{tabular}

Berdasarkan hasil tabel 4.4 aktivitas peserta didik memiliki 5 indikator kegiatan. Indikator kegiatan mental dengan tujuh aktivitas belajar peserta didik mendapatkan $49 \%$. Indikator menyimak dengan empat aktivitas belajar peserta didik mendapatkan $63 \%$. Indikator visual dengan satu aktivitas mendapatkan $73 \%$. Indikator menulis dengan satu aktivitas belajar peserta didik mendapatkan 38\%. Indikator kegiatan lisan dengan dua aktivitas belajar peserta didik mendapatkan 94\%. Rata-rata 5 indikator kegiatan mendapatkan 63\% dengan kategori "pasif".

Tabel 5. Hasil Rata-rata Persentase Aktivitas Peserta Didik

\begin{tabular}{ccc}
\hline Pertemuan Ke- & Rata-rata Persentase & Kategori \\
\hline 1 & $72 \%$ & Cukup aktif \\
\hline 2 & $61 \%$ & Pasif \\
\hline 3 & $63 \%$ & Pasif \\
\hline Rata-rata Persentase Total & $\mathbf{6 2} \%$ & Cukup aktif
\end{tabular}




\section{Hasil Belajar Peserta Didik (Post-Test)}

Hasil belajar (Post-Test) dilaksanakan pada tanggal 17 November 2020 kepada peserta didik kelas IV A tahun ajaran 2020/2021. Hasil belajar peserta didik didapatkan setelah materi keliling dan luas persegi bangun datar selesai dilaksanakan. Soal pada post-test ini berjumlah 12 soal dalam bentuk uraian. Adapun hasil dari post-test sebagai berikut

Tabel 6. Hasil Belajar Peserta Didik

\begin{tabular}{|c|c|c|c|c|c|}
\hline \multirow{2}{*}{ No } & \multirow{2}{*}{ Nama Peserta Didik } & \multirow{2}{*}{$\begin{array}{l}\text { Total } \\
\text { Skor }\end{array}$} & \multirow[b]{2}{*}{ Nilai } & \multirow{2}{*}{$\begin{array}{c}\text { Ketuntasan } \\
\text { Peserta } \\
\text { Didik } \\
\end{array}$} & \multirow{2}{*}{ Keterangan } \\
\hline & & & & & \\
\hline 1 & $\mathrm{AB}$ & 110 & 78,57 & 1 & Tuntas \\
\hline 2 & $\mathrm{AM}$ & 115 & 82,14 & 1 & Tuntas \\
\hline 3 & $\mathrm{AA}$ & 100 & 71,43 & 1 & Tuntas \\
\hline 4 & ANJ & 115 & 82,14 & 1 & Tuntas \\
\hline 5 & AFA & 115 & 82,14 & 1 & Tuntas \\
\hline 6 & $\mathrm{AP}$ & 55 & 39,29 & 0 & Tidak Tuntas \\
\hline 7 & DP & 140 & 100,00 & 1 & Tuntas \\
\hline 8 & DJ & 90 & 64,29 & 1 & Tuntas \\
\hline 9 & $\mathrm{FA}$ & 90 & 64,29 & 1 & Tuntas \\
\hline 10 & FS & 140 & 100,00 & 1 & Tuntas \\
\hline 11 & FAy & 95 & 67,86 & 1 & Tuntas \\
\hline 12 & GPPr & 125 & 89,29 & 1 & Tuntas \\
\hline 13 & KRR & 95 & 67,86 & 1 & Tuntas \\
\hline 14 & KA & 10 & 7,14 & 0 & Tidak Tuntas \\
\hline 15 & MR & 15 & 10,71 & 0 & Tidak Tuntas \\
\hline 16 & MAH & 90 & 64,29 & 1 & Tuntas \\
\hline 17 & NA & 85 & 60,71 & 1 & Tuntas \\
\hline 18 & $\mathrm{Nz}$ & 55 & 39,29 & 0 & Tidak Tuntas \\
\hline 19 & $\mathrm{RN}$ & 105 & 75,00 & 1 & Tuntas \\
\hline 20 & $\mathrm{Rn}$ & 80 & 57,14 & 0 & Tidak Tuntas \\
\hline 21 & $\mathrm{Sb}$ & 125 & 89,29 & 1 & Tuntas \\
\hline 22 & $\mathrm{SZ}$ & 90 & 64,29 & 1 & Tuntas \\
\hline 23 & SNA & 100 & 71,43 & 1 & Tuntas \\
\hline 24 & SSPA & 90 & 64,29 & 1 & Tuntas \\
\hline 25 & VAF & 140 & 100,00 & 1 & Tuntas \\
\hline 26 & $\mathrm{ZA}$ & 10 & 7,14 & 0 & Tidak Tuntas \\
\hline Tuntas & & & & 20 & $76,92 \%$ \\
\hline Tidak ' & htas & & & 6 & $23,07 \%$ \\
\hline
\end{tabular}

Berdasarkan tabel 6 hasil perhitungan dari 26 peserta didik terlihat bahwa sebanyak 20 orang peserta didik "tuntas" dan sebanyak 6 peserta didik "tidak tuntas". Jika dipersentasekan jumlah peserta didik yang melampaui ketuntasan adalah $76,92 \%$ dengan sedangkan jumlah peserta didik yang tidak tuntas adalah 23,07\%. Hasil perhitungan post-test dengan menggunakan media kertas origami pada pembelajaran 
matematika adalah $76,92 \%$. Hal ini menunjukkan bahwa hasil belajar peserta didik melebihi klasikal minimum yang sudah ditentukan.

\section{Efektivitas Penggunaan Kertas Origami}

Efektivitas penggunaan kertas origami dilihat dari tiga variabel yaitu kemampuan guru dalam melaksanakan pembelajaran, aktivitas peserta didik dan hasil belajar. Ketiga variabel saling berkaitan dan akan dikatakan efektif apabila mencapai Kriteria minimum baik. Adapun hasil dari penelitian yang dilihat dari ketiga variabel sebagai berikut.

Tabel 7. Hasil Efektivitas Penggunaan Kertas Origami

\begin{tabular}{lcc}
\multicolumn{1}{c}{ Variabel } & Hasil & Keterangan \\
\hline Kemampuan Guru Melaksanakan Pembelajaran & 2,74 & Baik \\
\hline Aktivitas Peserta Didik & $62 \%$ & Cukup aktif \\
\hline Hasil Belajar (post-tets) & $76,92 \%$ & Baik \\
\hline
\end{tabular}

Berdasarkan tabel 7 di atas, kemampuan guru dalam melaksanakan pembelajaran memeperoleh 2,74 dengan kategori "baik". Aktivitas peserta didik memperoleh hasil $62 \%$ dengan kategori "cukup baik". Hasil Belajar (post-test) memperoleh klasikal $76,92 \%$ dengan kategori "baik".

\section{Pembahasan}

Menurut Yusuf yaitu "pembelajaran dikatakan efektif bila semua indikator dimaksud mencapai kategori minimal baik"(Yusuf, 2018: 20). Menurut Kyriacou (2011:15) ada tiga kelas variabel terpokok yaitu "variabel konteks, variabel proses dan variabel produk" dimana ketiga konteks ini saling berkaitan. Berdasarkan pendapat ahli, hasil penelitian yang dilakukan bahwa efektivitas penggunakan kertas origami pada materi keliling dan luas bangun datar di SDN 05 Pontianak Timur dikatakan tidak efektif yaitu 1) Kemampuan guru melaksanakan pembelajaran menggunakan kertas orgami dengan kategori baik, 2) Aktivitas peserta didik dengan kategori cukup aktif dan 3) Hasil belajar peserta didik dengan kategori baik.

Menurut Rusman (2016: 126) "Hal lain yang harus dipantau dalam kegiatan pembelajaran adalah adanya perangkat pembelajaran berupa silabus dan RPP sehingga pelaksanaan pembelajaran lebih terarah untuk mecapai kompetensi yang diterapkan". Berdasarkan pendapat tersebut penelitian ini menggunakan RPP yang dirancang agar penelitian pada pelaksanaan pembelajaran lebih terarah. Pada indikator kemampuan guru mengajar dilihat dari keterlaksanaan pembelajaran yang memiliki $R G K_{\text {total }}$ sebesar 2,74 dengan kategori "Baik". Hal ini juga diperkuat oleh penelitian sebelumnya yang dilakukan oleh Ida Farida, "kemampuan guru dalam melaksanakan pembelajaran menggunakan media manipulatif mengalami peningkatan pada setiap siklus" (Farida, 2019: 117).

Adapun skor rata-rata kemampuan guru menggunakan kriteria sebagai berikut.

Tabel 7. Skor kemampuan guru

\begin{tabular}{cc}
\hline Rata-rata & Kriteria \\
\hline Rata-rata $\geq 3,5$ & Sangat Baik \\
\hline $2,5 \leq$ Rata-rata $<3,5$ & Baik \\
\hline $1,5 \leq$ Rata-rata $<1,5$ & Cukup \\
\hline $0,5 \leq$ Rata-rata $<1,5$ & Kurang \\
\hline Rata-rata $<0,5$ & Sangat kurang \\
\hline
\end{tabular}

Khabibah dalam Nuriah (2019:52)

Aktivitas belajar adalah kegiatan belajar mengajar yang dilakukan oleh pengajar dan peserta didik" (Yusuf, 2018: 19). Aktivitas peserta didik dalam penelitian ini 
menggunakan satu observator dengan 15 indikator aktivitas. Berdasarkan hasil penelitian yang telah dipaparkan sebelumnya aktivitas peserta didik memperoleh kategori cukup aktif. Aktivitas peserta didik pada penelitian ini tidak mencapai kategori aktif. Hal tersebut dikarenakan pada saat proses pembelajaran peserta didik keluar masuk aplikasi karena koneksi internet yang buruk dan kurang terlihatnya aktivitas peserta didik pada saat proses pembelajaran. Adapun persentase aktivitas belajar peserta didik sebagai berikut.

Tabel 8. Skor Persentase Aktifitas Belajar

\begin{tabular}{cc}
\hline Persentase & Kriteria \\
\hline $85 \% \leq$ persentase $\leq 100 \%$ & Sangat Aktif \\
\hline $75 \% \leq$ persentase $<85 \%$ & Aktif \\
\hline $60 \% \leq$ persentase $<75 \%$ & Cukup Aktif \\
\hline $55 \% \leq$ persentase $<60 \%$ & Pasif \\
\hline $0 \% \leq$ persentase $<55 \%$ & Sangat Pasif \\
\hline
\end{tabular}

(Massita, 2018: 61)

Hasil belajar (post-test) dilakukan pada tanggal 17 November 2020 di rumah peserta didik masing-masing. Menurut Sudjana (2016:22) "hasil belajar adalah kemampuankemampuan yang dimiliki siswa setelah ia menerima pengalaman belajarnya". Berdasarkan pendapat ahli diatas hasil penelitian ini diambil setelah melakukan pembelajaran. Pada saat melakukan tes peserta didik dipantau melalui google meet dengan link https://meet.google.com/uqb-jayw-yub. Tes subjektif pada umumnya berbentuk uraian dan objektif dilakukan secara objektif. "tes uraian terbagi menjadi tiga yaitu tes uraian bebas, uraian terbatas dan uraian berstruktur, sedangkan tes objektif terdiri dari pilihan benar-salah, pilihan ganda, menjodohkan dan isian pendek atau melengkapi" oleh Sudjana (2009:35). Berdasarkan pendapat tersebut penelitian ini menggunakan soal berbentuk isian singkat sebanyak 12 soal. Peserta didik mengerjakan soal dalam waktu 120 menit. Dilihat dari tabel 4.6 peserta didik yang dapat melampaui ketuntasan sebanyak 20 orang, hasil persentase yaitu $76,92 \%$ dengan kategori "Baik". Hal ini juga diperkuat dengan penelititan sebalumnya yaitu Ida Farida hasil belajar siswa dalam pembelajaran matematika menggunakan media manipulatif mengalami peningkatan oleh Farida (2019:118). Adapun faktor ketuntasan dalam penelitian adalah keterbatasan pengawasan peneliti dalam melaksanakan post-test, adanya peran orang tua dalam pengerjaan soal post-test, peserta didik memahami materi keliling dan luas bangun datar. Ketiga faktor ini mempengaruhi ketuntasan peserta didik.

Tabel 9. Kriteria Pesentase Hasil Belajar

\begin{tabular}{cc}
\hline $\begin{array}{c}\text { Penskoran Skor } \\
\text { (Skala 0-100) }\end{array}$ & Kriteria \\
\hline $85 \leq$ skor $\leq 100$ & A (Sangat Baik) \\
\hline $75 \leq$ skor $<85$ & B (Baik) \\
\hline $60 \leq$ skor $<75$ & C (Cukup) \\
\hline $50 \leq$ skor $<60$ & D (Kurang) \\
\hline $0 \leq$ skor $<50$ & E ( Sangat Kurang) \\
\hline
\end{tabular}

(Yusuf, 2017:14)

\section{Simpulan}

Berdasarkan hasil data, pengolahan data, analisis data dan hasil penelitian yang telah dilakukan bahwa efektivitas penggunaan kertas origami dalam pembelajaran materi keliling dan luas bangun datar kelas IV di Sekolah Dasar Negeri 05 Pontianak Timur dikatakan tidak efektif dengan rincian subbab masalah sebagai berikut.

1. Kemampuan guru mengajar dengan menggunakan media kertas origami pada materi keliling dan luas bangun datar memiliki $R K G_{\text {total }}$ sebanyak 2,74 dengan 
katagori baik. Hal ini menunjukkan bahwa kemamuan guru dalam melaksakan proses pembelajaran melampaui kriteria.

2. Aktivitas peserta didik dengan menggunakan media kertas origami pada keliling dan luas bangun datar memiliki persentase $62 \%$ dengan katagori cukup aktif, hal ini menunjukan bahwa aktivitas peserta didik tidak mencapai kriteria aktif.

3. Hasil belajar peserta didik dengan menggunakan media kertas origami pada keliling dan luas bangun datar memiliki persentase 76, 92\% dengan katagori baik, hal ini menunjukan bahwa hasil belajar peserta didik melampaui kriteria.

\section{Saran}

Adapun saran yang disampaikan berdasarkan hasil penelitian sebagai berikut.

1. Sebaiknya soal berbentuk essai untuk menuntut kepahaman peserta didik.

2. Apabila menggunakan soal berbentuk essai diharapkan jumlah soal tidak banyak.

3. Observator diharapkan lebih dari satu sehingga dapat membandingkan hasil observasi dalam penelitian dan hasil yang diharapkan sesuai dengan harapan pada penelitian ini.

4. Instrumen penelitin di validasi lebih dari satu validator, sehingga dapat menghasilkan instrumen yang valid.

\section{Referensi}

Arsyad, A. (2014). Media Pembelajaran. Jakarta. PT. Rajagrafindo. Persada

Dewabrata, M. (2019). Hasil PISA 2018 Resmi diumumkan, Indonesia Alami Penurunan Skor di Setiap Bidang. Zenius. Diunduh di https://www.zenius.net/blog/23169/PISA-20182-2019-Standar-Internasional

Farida, I. (2019). Peningkatan Hasil Belajar Siswa Menggunakan Media Manipulatif pada Pembelajaran Matematika Kelas V Sekolah Dasar Negeri 04 Pontianak Barat. Skripsi. Universitas Tanjungpura

Kyriacou, C. (2011). Effektive Teaching Theory and Practice. Bandung. Nusa Media

Massita. (2018). Efektivitas Pembelajaran dengan Pendekatan Pendidikan Matematika Realistik pada Materi Kubus dan Balok di SMP. Universitas Tanjungpura

Muhsetyo, G. (2011). Pembelajaran Matematika SD. Jakarta. Universita Terbuka

Nuriah. (2019). Efektivitas Penerapan Teori Brunner pada Materi Menghitung Luas Persegi dan Persegi Panjang Kelas III SD. Diunduh di https://jurnal.untan.ac.id.index.php/jurnalkpk/article /view

Rusman. (2016). Model-model Pembelajaran. Jakarta. Bumi angkasa

Sudjana, N. (2016). Penilaian Proses Hasil Belajar Mengajar. Bandung. Remaja Rosdakarya.

Sugiyono. (2019). Metode Penelitian Kuantitatif, Kualitatif, dan $R \&$ D. Bandung. Alfabeta

Sundayana, R. (2014). Media dan Alat Peraga dalam Pembelajaran Matematika. Bandung. Alfabeta

Syaodih, N. (2016). Metode Penelitian Pendidikan. Bandung: Rusda

Yusuf, B. B. (2017). Konsep dan Indikator Pembelajaran Efektif. Jurnal Kajian Pembelajaran dan Keilmuan, 1(2), 13-20. 